\title{
DEMYSTIFYING THE MYTH OF COSMOPOLITANISM: ARE WE TRULY LIVING IN A BORDERLESS WORLD?
}

\author{
Aspin Nur Arifin Rivai \& Gema Ramadhan Bastari \\ UIN Alauddin Makassar \& Pemuda Pekerja Indonesia \\ Email: askaspin@gmail.com \& gemarbastari@ gmail.com
}

\begin{abstract}
This paper will discuss about the possibility that cosmopolitanism as an idea might only exist as a myth. It begins by questioning the hypocrisy surrounding our everyday life where powerful countries preach about living in dignity but ended up taking away that very dignity itself. If cosmopolitanism is defined as an idea that give worth to every human being, no matter their affiliation, then the current state of the world does not reflect that idea at all. This paper will attempt to demystify the practice of cosmopolitanism in modern era. This paper then found that cosmopolitanism is basically a political project for the powerful to inject their idea into weaker actor, in order to create hegemony. Whether someone's act can be considered cosmopolitan or not depends on their capability to exercise their power. In the end, this paper concludes that cosmopolitanism as a standard of morality does not exist in our world. A borderless world might exist, but it is up to the powerful to decide who can live in it. For most people, cosmopolitanism remains a myth that could never bring salvation.
\end{abstract}

Kata kunci: Cosmopolitanism, Morality, Hegemony.

\section{INTRODUCTION}

There is a bit of story that the author remember from the extraordinary tale of Superman. It was a story about Superman saving people in a country that resembles Iraq from a dictator that resembles Saddam Husein. Now Superman is known as the symbol of hope, the superhero that will fly at the speed of sound, traversing even time and space, to save anyone from evil. Yet for every superhuman feats that the Man of Steel was capable of, it is very rare to see a depiction of Superman saving lives other than your average American white guy. Nevertheless, what Superman said to the people he saves in that Middle East-esque country was devastating: “I'm sorry. I don't speak Arabic. But I should. I'll learn. I should have been here all along. I'm sorry. I'll stop this." This trembling speech that Superman made as he brought the evil dictator to justice is closely reflecting the very nature of cosmopolitanism in modern era. Many countries have the power to save the world, promoting the idea thoroughly, yet no one is willing to lift a finger to do any meaningful things to realize it.

\footnotetext{
${ }^{1}$ This is a story depicted in a graphic novel published by DC Comics in 2016 titled Injustice: Gods Among Us Vol. 1 Ch. 6.
} 
The world that we currently living in is full of hypocrisy and cosmopolitanism is no small part of it. Long ago, the world has agreed that the end of Cold War means 'the end of history'. That there will be no value that can be upheld except the liberal value. That freedom, openness, and diversity will stand tall and be fought upon from any kind of enemies. That the Global North will help to eradicate poverty in the Global South and so on (Fukuyama, 1989).

At the end of 2016, we can see that all of this farce has begun to crumble down. Poverty is still high as ever in African countries and violence remains the staple of their everyday life (The economics of violence, 2011). The global wealth is still concentrated in most Western countries although it begins to shift gradually to the East (which does not makes any difference as the zero-sum logic is still applied). ${ }^{2}$ The Syrian refugee crisis only shows how reluctant ${ }^{3}$ the European countries to lend their hand for people who needs it the most (Sobelman, 2015). To top it all off, the two most prominent supporter of cosmopolitanism, the United Kingdom (UK) and the United States (US) has changed their position dramatically. With UK getting out from the European Union and Donald Trump leading US, they no longer have any credibility to further the cosmopolitanism agenda. ${ }^{4}$ The fact is, the end of history is still far from our reach and the world is still doomed to repeat the same mistake over and over again.

If cosmopolitanism is an idea that each person owes their moral obligation to everyone without exception, then the current state of the world certainly does not reflect that idea at all (Johnson \& Cureton, 2016). However, it cannot be denied that the infrastructure to make cosmopolitanism possible does exist. The advancement of information, communication, and transportation technology in the past decade has

\footnotetext{
${ }^{2}$ The Global Wealth Report in 2016 recorded that nearly $71 \%$ of the world holds only 3 percent of global wealth while about $8.1 \%$ of population owns $84.6 \%$ of it (Facts about Global Inequality, 2016).

${ }^{3}$ Only few European countries are willing to accept Syrian refugee who fled from the civil war in their country - mostly Gulf State. France, Germany, and Britain accepted some of them but then close their border because they thought that have had enough. As a result, nearly 400 refugees drowned in their overloaded boat as no country willing to open their beach for them to dock (Koser, 2013).

${ }^{4}$ UK's exit from European Union is seen as a decision that backlashes the idea of openness and borderless world by making UK more isolated and more harmful toward immigrants. While Trump's presidency has devolved the US into a merchantilist state who could care less about free trade or multilateralism as well as having the same harmful behavior toward immigrants. Together, these two phenomenon is said to be the beginning of the collapse of liberal idea in the west (Walt, 2016).
} 
shortened the amount of time needed for people around the world to interact with each other. In front of these advanced technologies, borders between states can be amounted to nothing (Bulut, Cakmak, \& Kara, 2013).

Yet despite all of this fact, cooperation between states remains awkward as ever. Direct interaction between people is still limited by the status of their visa. Some countries even censored their internet to prevent their people from interacting with outsider. ${ }^{5}$ Global citizenship is still merely a concept far detached from reality (Liu, 2012). It is very regretful that with every bit of power invested to the people in this era, none of it is being used to fulfill the very cosmopolitanism agenda that we hear every day. It's just like the Superman story all over again. All this power but it has never been used to its maximum potential.

This paper will contemplate upon the question of whether we truly live in a borderless world or not. Is cosmopolitanism a real and practical idea or is it just a myth to further western hegemony? Is there any chance for the people to ever see a borderless world? Are we doomed to live in the cycle of hatred and violence forever? In order to answer this seemingly endless question, this paper will track the origin of cosmopolitanism as an idea, starting from its birth, its development in literatures, and its interpretation in modern era. Then, this paper will unmask the practice of cosmopolitanism in contemporary era to show how meaningless they are. Finally, this paper will ponder over the relevance of cosmopolitanism today. Is it still matter? Have it even matter in the first place? Are we, perhaps, never really needs that idea after all?

\section{THE ORIGIN OF COSMOPOLITANISM}

Is the idea of cosmopolitanism still relevant today? Is the uncertain history narrative in the $21^{\text {st }}$ century embedded with experiences of never-ending conflict still needs the cosmopolitan idea? Is the unity such as explained by the 'cosmos' means the same thing in the Eastern and Western civilization? The discursive development of cosmopolitanism remains strong between scholars and activists to create a discourse called "The new world order." This term becomes an enigma for contemporary situation. One one

\footnotetext{
${ }^{5}$ China has been infamous for its notorious internet censorship. Social media is not even allowed in that country and most international news went into several revision from the government before finally being published. This system is known by its nickname 'The Great Firewall' (Haas, 2017).
} 
hand, this concept is understood differently between different people. On the other hand, effort to create the concept of 'cosmopolitan', which seems to be merely 'stylish catchword' by defining it in a comprehensive way, makes the term so wide and elusive.

Cosmopolitanism came from a normative project said to be an idealism that can be implemented. Cosmopolitanism tries to break the civilization which always narrating evil, savagery, and banality. The idea of cosmopolitanism invites the people to create a civilization based on order, peace, and justice. However, the idea brought by cosmopolitanism is still debatable. There are two points of contention for this idea: (1) what is the possibility to create a cosmopolitan world order? and (2) what the cosmopolitan world order would look like? The cosmopolitan tradition in philosophical thinking is everchanging. First from Greek's philosophical tradition, claimed as a way of life, but in the most abstract sense. Then, cosmopolitanism gained its momentum in international politics when Kantian tradition resonates with the world in conflict.

Stoicism was the first idea for those who call themselves a cosmopolitanist. This idea was realized by replacing the centralistic role of 'polis' in ancient greek with 'kosmos' where mankind can live together in harmony (Held, 2005, p. 10). People then live in a local community and ideal community with wider arguments and aspirations. The idea was also called with pluralism, an idea where morality becomes their modality to live together, not with ethnic categorization, social class, or nations. Finally, it becomes an awareness of collectivity (Nussbaum, 1997, p. 30).

Meanwhile, the second concept of cosmopolitanism was introduced by Immanuel Kant ( $18^{\text {th }}$ Century) with the name international society (Weltbürger) as an instrument of the enlightenment era. Kant connects the idea of cosmopolitanism with an innovative concept about "the public of reason" and explores ways in which this conception can produce a critical perspective to understand civil society (Schmidt, 1998). By building the definition of enlightenment as an escape of false dogma and authority, Kant calculates its development by abolishing the limitation in "the usage of logic in general." For Onara O'Neill, he agrees that the principle of logic is the right reason to secure the possibility of intersubjectivity (O'Neill, 1990, p. 194). Kant understands that people's participation in cosmopolitanism cannot be separated with open dialogue (full participation) - and this becomes an instrument of rights for everyone on earth (Held, 2005, p. 11).

Garret W. Brown and David Held depicts cosmopolitanism a la Kantian as a part of moral and political project directed to ask the very basic question of: how to realize the 
principle of cosmopolitanism and how to reform the existing institutional order or how to plan it. The two thinker then identifies five intertwined issues faced by contemporary cosmopolitanism: (1) global cosmopolitan justice; (2) cultural cosmopolitanism; (3) cosmopolitanism in law; (4) political cosmopolitanism; and (5) cosmopolitanism in citizenship (Brown \& Held, 2010).

Global cosmopolitanism justice cannot be separated with issues regarding inclusive justice, while cultural cosmopolitanism tries to understand - how to develop global justice in the middle of cultural heterogeneity. Then, cosmopolitanism in law is related with international law, political cosmopolitanism with global governance and cosmopolitan citizenship with cosmopolitan nation-building. If seen from much smaller scale, then cosmopolitanism refers to two fundamental dimension between politics and culture (Hannerz, 2006).

Cosmopolitanism as a philosophical politics - the main idea of cosmopolitanism is that every human is part of a single community or category and so must be treated equally, despite of differences in their social and political status (Brock \& Brighouse, 2005). Cosmopolitanism views every individual in the highest appreciation for their existence. This kind of view is believed to be essential to any kind of social institutions. Therefore, people cannot be treated as an instrument of social value or treated differently because of artificial attribute such as citizenship.

Cosmopolitanism as a cultural framework refers to an idea that people from different cultural context must be treated equally. This was realized by an openness to diversity, tolerance, non-discriminative, and willingness to see others as equal (Sugiono, 2012, p. 224). The politics of cosmopolitanism can be seen as a political project, that is: a critical and transformative political philosophy. It has a dream to change all social order which rejects the idea that all human are born equal. The manifestation of political cosmopolitanism takes a normative form in an international institution which is a common thing in contemporary international system.

In the middle of $20^{\text {th }}$ century, the cosmopolitan dream is an inspiration to fix international system through rearrangement of international law and institution which gives 
birth to League of Nations and the United Nations (UN). ${ }^{6}$ The goal was very ambitious: to create international peace and defend human rights. Then, the cosmopolitan idea becomes popular as a theoretical source that can be used to understand the world, an instrument to understand our life, a prescription for a normative behavior in upholding universality, international law, and political action (Fine, 2003, p. 452).

Moreover, cosmopolitanism gets attention in contemporary era as it is a way to understand the socio-cultural implications, political relations, which goes beyond state's demarcation. However, this idea was laughed at by classical realism thinker who called it utopist, because it (cosmopolitanism) views the state of anarchy with naivety. The fundamental change in cosmopolitanism in contemporary era is from 'a way of life' into 'a spirit of life'.

Currently, political cosmopolitanism has brought democracy as the best system to be implemented, no matter what state it is. Democracy, through cosmopolitanism, has become an international norm. Because of that, human rights violators are getting mocked, as well as the rigid and obsolete principle of sovereignty which protects the violators. They popularized the idea in international platform by fighting upon the idea of cosmopolitan citizenship and offered the creation of a global governance ${ }^{7}$ to make sure that human rights are fulfilled for every individual, no matter from which nations (Taraborrelli, 2015).

The definition of cosmopolitanism can be said as an idea to move beyond the limitation of politics, community, territory, and culture to build another loyalty for a community of mankind. This definition is also justified as a new political variant perceived as an ideal for the globalizing world. If this can be considered as a full definition, then the next debate will be: how far cosmopolitanism as a political principle and cultural commitment can be compatible with nationalism? This question will be answered in the next discussion, but the author wants to offer the most fundamental debate,

\footnotetext{
${ }^{6}$ Cosmopolitanism exists as an idea in the UN, especially in its charter that mentions how human has the power of international law and self-determination Invalid source specified..

${ }^{7}$ Critics most seen from cosmopolitanist in global politics are materialized in the campaign to create a global governance or a governance without government Invalid source specified.. This idea is a part of political order developed in the wake of globalization that seems to abolish the territory between nation-states. More importantly, it is viewed as a mechanism or institutional apparatus for cooperation between actors, state or non-state, to deal with problems arises as a logical consequences of globalization Invalid source specified..
} 
that is: how the normative aspect of morality in cosmopolitanism can be relevant in the middle of some crucial contemporary issues.

In those debates, the cosmopolitan discourse can be underlined in this areas: (1) how the research on cosmopolitanism can answer questions regarding its ideas, dreams, and implementation as a normative institution in global political order; (2) how the research on cosmopolitanism will be relevant to explain globalization as a phenomenon; (3) how the research on cosmopolitanism experiences dichotomy between culture, politics, law, etc. From theoretical perspective, it seems that contemporary cosmopolitanism does not give enough space for morality.

Morality or its standardization is obviously relevant to understand the world today and how it should be. Contemporary research on cosmopolitanism is simply skipping to the creation of a normative institution, but ignores the very foundation of cosmopolitanism that is the practice of morality. Because of that, problems arise within normative institution, such as the case of UN Security Council which has a controversial authority.

Moreover, the dimension of morality in mainstream cosmopolitanism agenda has not able to create a standard of morality in international community. In fact, the universality value to uphold human rights are sometimes violated by nation-states. It means that global practices in modern era has not changed in the least. Although the end of Cold War should have brought forward a global integration, cosmopolitanism has not given significant contribution to redefine morality in that agenda of integration.

On the other corner, Muhadi Sugiono mentioned that even in the implementation of cosmopolitanism in international stage, it tends to be isolated merely in the discipline of International Relations. This happened because International Relations is seen to be inseparable from Political Science - which views the world as a political arena for nationstates to fight their interest.

In conventional International Relations paradigm, it is impossible to view the world in unison. That view is definitely misleading because International Relations itself is having development in order to better understand the unpredictable nature of international system. In 1980s, some scholars appear to argue how 'idea matters' in International Relations. That new arguments make idea as another crucial possibility to be debated, especially between scholars of liberalism, constructivism, and post-positivism. Starting from an assumption that idea matters, they began to theorize how the immaterial aspect of 
the world shapes the very world itself. This theoretical space makes it possible for cosmopolitanism to realize their idea.

\section{DEMYSTIFYING COSMOPOLITANISM: HOW THE WORLD COMPETES OVER THEIR UTOPIA}

If history ever taught us anything, it's that the word of Man cannot be trusted. Cosmopolitanism, as Kant stated, is perceived as a universal value that gives worth to every human being, not because of their religion, tribe, nation, state or any affiliation, but simply because they are part of the same species (Johnson \& Cureton, 2016). Yet what is deemed universal will always fall to one's own subjective moral compass. Take a look at the Universal Declaration of Human Rights.

The Declaration speaks in-length regarding how human rights must be upheld and protected. But when it comes to defining what kind of human rights that they were talking about, the Declaration felt more like a collection of western morality worded cleverly to be adopted by the rest of the world. ${ }^{8}$ While it is true that human lives should be treated as essential, the way they live should also be considered the same. The Declaration wants people to live in dignity, free from fear and poverty, but those words have no weight when the founder of that charter is the same people who rob the world of that freedom itself. ${ }^{9}$ In that sense, even the most universally-perceived product that the human race has ever brought has its own partiality. If we can at least agree that cosmopolitanism is a normative value, then that very norm must be thoroughly questioned as well.

\footnotetext{
${ }^{8}$ As a concept, human rights is not an invention of the Universal Declaration of Human Rights. Different societies and cultures have practiced and created their own version of human rights in the past. Even Arab countries, who were mostly criticized for their lack of human rights when it comes to treating women, actually have their own value on human rights which justifies that behavior. Therefore, the universal value of Human Rights brought by the Declaration can actually contradict with the morality of certain society. The thing about Universal Declaration of Human Rights is not whether it is good or bad but whether it is truly universal (as in transcendentally universal) or merely claimed to be (Donelly, 2007). This paper believes the latter.

${ }^{9}$ It is quite oxymoron for the charter to expect people to live free from fear and poverty when the US who was the founder of that charter is currently the biggest threat for every people in the world. There is no telling when that country will declare that you and your family are a terrorist that must be pursued and eliminated without prosecution before law. And with their military base surrounding every part of the planet as well as the nuclear bomb in their possession, how can the people possibly live without being afraid of the potential destruction that the US can cause? (Chomsky, 2015)
} 
Now building a cosmopolitanism world order is akin to building a heaven on earth - a utopia. However, just like the Universal Declaration that we discussed earlier, people have their own view on what a utopia is. As it is a view governed by their-own subjective moral compass, sometimes it can be very twisted and ugly. Let's talk about Hitler because his existence has been portrayed as the poster child of anti-cosmopolitanism idea. People condemned Hitler because he has no affection to people outside the Aryan race and by having no affection means that he can murder them at will (Hicks, 2009). But the thing is, Hitler does not view non-Aryan race as a human being at all. With that kind of twisted logic, Hitler, in his own way, is a cosmopolitan figure as he gave his affection to every Aryan Race (whom he thought as the only human being in this planet) in any part of the world. This argument might be ugly but this is actually how cosmopolitanism works in this world.

Have you ever heard about homo sacer? It is a concept famously coined by Giorgio Agamben to portray how some part of the society can be sacrificed if the sovereign said so. As stated by Carl Schmitt, the sovereign is "he who decides on the state of exception." Homo sacer lives in that state of exception. To common eyes, a homo sacer might look just like normal human being but to the sovereign, their worth is amounted next to insects. Their very lives belong to the will of sovereign to be played as they see fit. If the sovereign wills the homo sacer to die, then die they will (Agamben, 2005). What Hitler did is simply making every human beings apart from the Aryan race as a homo sacer. If Hitler won the World War II and he became the true sovereign of this world, then his view would definitely be seen as cosmopolitan. Unfortunately, Hitler lost that war and the right to decide on the state of exception falls to the US instead. Do not even bother to think if it's good or bad because your judgment will definitely be clouded by their influence as the leader of free world. The only thing that can be inferred from this paragraph is that power decides on whether your action can be called cosmopolitan or not.

As the most powerful country in this world, countless human has been transformed into a homo sacer by US' will. In their own territory, we have the indigenous people of Indian who was named that way because the US likes that name. Then, they were forced out of their territory, stripped of their rights and alienated from the society (Khazaal, 2016). There are also the Black people, the Asians, the Hispanics, and every non-White immigrant who is forced to live without dignity next to the wealthy White (Dudek, 2015). 
While outside of their territory, we have the people of Vietnam, the people of Iran, the people of Iraq and every human being whom they suspect as a terrorist and many more. The US might not use genocide in those cases, but they do find a way to make living miserable for those people (Chomsky, 2015).

In their view, the sacrifice of those people is essential in order to create their own utopia - a borderless world where White people are fully-educated, able to move freely, and seize opportunity from anywhere. ${ }^{10}$ That idea might sound as a very cosmopolitan idea for White people but definitely not for the others. This is the true face of cosmopolitanism in modern era: a very communitarianism ${ }^{11}$ idea masked and marketed as a universal idea by eliminating people outside of their selected view.

In the past, there have been countless people who tries to resist US' cosmopolitanism by instilling their own version. The Indonesian President, Soekarno, tries to create a world where post-colonial countries can live proudly and free from fear. However, in order to realize that idea, he must transform all of the White people into a homo sacer. He did exactly that by nationalizing every western company in Indonesia and forces them out from his territory. Then, he also invade the people of Malaysia whom he thought obstructing his idea of cosmopolitanism (Redfern, 2010). If only Soekarno has a real power, then a cosmopolitan world order for Asian and African people might actually became a reality. There is also the case of Muammar Gaddafi, Vladimir Lenin, Fidel Castro and many others with their own version of cosmopolitan world order which requires the sacrifice of certain people. All of them failed because of their lack of power, but it clearly portrays how the world has competed over which utopia is better.

Another way to realize the cosmopolitanism idea is by limiting your own world. If you do not have the power to sacrifice others, then your only option is to build a wall around you which can only be entered by your selected few and make sure that they don't

\footnotetext{
${ }^{10}$ It is no secret that free movement is much easier for White people than for the rest of the world. White people entering another country will be welcomed to invest or to work as an expatriate. Meanwhile, Asians, Middle-eastern, or black people will first be suspected as a drug dealer or terrorist before they can prove otherwise. Even if they decide to exercise their right to free movement, non-White people have only little opportunity to work on a better job. Basically, migration of white people is seen as a positive outcome of free movement while migration of the others is seen as a disastrous and unwanted effect of free movement (Koutonin, 2015).

${ }^{11}$ Communitarianism is an idea that we only owe our moral obligation to our kin or community. This paper is trying to say that cosmopolitanism is no different but is able to be perceived as universal by eliminating people outside of their community (Johnson \& Cureton, 2016).
} 
know about anything outside that wall. The North Korea has practiced this for many years. Within their border, the people hailed their leader as a compassionate person who cares deeply for his people (Rose, 2015). Having no information of the world outside of their border, it is easy for them to identify it as a cosmopolitan world order.

However, another brilliant idea comes from regionalism. You can erase borders between states in your region, eliminating tariff to allow free movement of goods, and promoting unity, but you build a wall surrounding that region to make it harder for people outside of it to enter (Spindler, 2002). Within that regional border, a cosmopolitan world order can be realized where the selected few can merge with each other and melt into a universal society according to their own sets of morality. Still, the case of ASEAN shows how great power cannot possibly allow that to happen. This can be seen from US' constant interception to force ASEAN adopting their view of cosmopolitanism and how they demonize closed regionalism as a bad fortress mentality and promoted the idea of open regionalism to make ASEAN more open to the rest of the world (Koga, 2013).

The biggest hindrance of true universal cosmopolitanism in this world is the existence of nation-state. By definition, nation-states are created as a social contract among its people to prioritize their needs first before others. As a technology, state is created to pursue the interest of their people and their people only. Therefore, when a nation-state champions a cosmopolitan agenda, their very first priority will be the benefit it will bring to their people. The competing view of cosmopolitanism as explained above is simply a logical consequence brought from the nature of nation-state. Yet despite how nation-state obstructs the creation of true heaven on earth, their existence remains essential to preserve the basic value of human life. As can be seen from the case of stateless people, people's lives are much easier to be played with if they have no protection from the nation-state.

There is a reason why the creation of a nation-state is often interpreted as an 'independence day' since the people of the newly-founded state will then be able to have a protection for their basic human rights (although states can also be the robber of that very human rights itself, such as what happened in the case of Rwanda). Even Kant seems unable to answer this delicate dilemma when he argues about the creation of a "federation of peoples." According to him, this federation cannot be considered the same as an international state since he also considered the rights of state in that federation. The problem is, Kant cannot clearly answer how that "federation of peoples" can have more 
power than the state. After all, if state remains the most powerful actor in the world order, than true cosmopolitanism will remain impossible (Cronin, 2009).

In the end, cosmopolitanism in modern era can only be seen as an instrument of the powerful to instill their-own set of morality and present it as a universal value. There is a borderless world and a global citizenship but it's for the powerful to decide on who can live in it and identify themselves as one. No wonder that the people who call themselves cosmopolitan are mostly of the same kind: the wealthy, privileged, and elitist people who enjoy talking with their racially-diverse yet uniformed people about how they love humanity but in actuality they only talk about themselves. A global citizen as it is now is no less than a tribe pretending to represent every part of humanity (Douthat, 2016). There can never be a utopia for everyone. A universal value is only possible under the guidance of an objective body of thought that transcends humanity itself. A universal value created by Man will always be limited by their-own subjective moral compass. So either you comply with the rule of the powerful or retreat and create your own world. Neither option is ever close to the ideal that Immanuel Kant fantasized when he discuss about the concept of cosmopolitan world order.

\section{CONCLUSION}

\section{MOVING FORWARD FROM COSMOPOLITANISM}

The previous chapter should probably give you an idea as to why you should question cosmopolitanism as an idea. Despite how good it is on paper, the idea is barely realistic and outright impossible due to its limitation caused by Man's subjective moral compass and the very existence of state itself. However, the root of that idea has contributed a lot to the morality debate in international relations.

At very best, the idea serves as the highest standard of moral practice to be imposed by politicians. It evokes debates and questions of whether or not we should cooperate to help people in different countries. Although most of the time that debate did not turn into a real policy, the fact that cosmopolitanism can trigger that kind of debate is already contributing enough. It at least helps us to realize our own humanity that we probably forgot when we watch too many television shows about corrupt politicians on stage. But then again, it does not change the fact that cosmopolitanism as an idea has lost its influence recently. 
British exit from European Union (or 'Brexit' as they put it) has shown us time and time again that mankind is not meant to live together in harmony. The vote to leave the EU was made based on fear for immigrants. The majority of White and privileged but less educated British simply cannot stand the idea of living together with Polish immigrants. They called these Poles a 'vermin' and they blame the Poles for their lack of jobs and the high number of criminal activity.

After the vote for Brexit was made, the message to 'get out!' was yelled at these Polish people. As the racism activity increased in UK, the majority of Polish immigrant was forced to choose either packing their belongings or bearing the bigotry even further. What the British people did with Brexit is basically unmasking the human race and shows them for what they are. People could care less about cosmopolitanism, about integration, or even about harmony. In their mind, all those flashy words are just plaything for politicians to involve their country in an experimentation that probably beneficial for them but do not give anything to the people. What they truly care is to live in their comfort zone, with enough income and to share it with their beloved family or friends. Cosmopolitanism did not give that, it only gives cultural shock.

The case of Brexit shows how even the Great Britain who used to preach about the importance of international cooperation eventually realized how they never liked the idea in the first place. This makes the author think, is cosmopolitanism as an idea truly necessary? If we can exercise our thought to imagine a borderless world where people can live together in harmony without conflict, will it be a good world to live in? As a matter of fact, humanity managed to become the most superior race on this planet by rising from the ashes of conflict. A horrible war in $16^{\text {th }}$ Century led to the creation of the Westphalian System in 1648. The two biggest wars in the history led to the creation of United Nations. The Cold War makes way for an idea that trust between communities is important and strengthen the United Nations even further. After all of this, can we still say that conflict is unnecessary? The author would like to think that everything is not as simple as it seems. After all, it is still a fact that conflicts are what define us as a human race.

The best that we can interpret from the idea of cosmopolitanism is as a 'daydream'. A dream belongs to the privileged who views the world from a safe place up there in the Ivory Tower. A cosmopolitan world order in their dream must have been a pretty nice place to live in. But when the idea is truly implemented and the peasants start to live in the 
same safe haven as them, they finally woke up from their dream and realize how horrible their situation is. So they begin to reject the very idea they proposed as an effort to cast away the very people they invite in the first place. Such is the tragedy of cosmopolitanism in contemporary era. So to answer the first question of this paper - yes, cosmopolitanism is indeed a myth. A myth that we try so hard to realizes without realizing the futility of that effort. Perhaps, the Superman that we have waited for so long is only living inside the fabric of our imagination.

\section{REFERENCES}

The economics of violence. (2011, April 14). Retrieved Agustus 17, 2017, from The Economist: http://www.economist.com/node/18558041

Facts about Global Inequality. (2016). Retrieved Agustus 17, 2017, from Inequality.org: https://inequality.org/facts/global-inequality/

Agamben, G. (2005). State of Exception. London: University of Chicago Press.

Brock, G., \& Brighouse, H. ( 2005). The Political Philosophy of Cosmopolitanism. Cambridge: Cambridge University Press.

Brown, G. W., \& Held, D. (2010). The Cosmopolitanism Reader. Cambridge: Polity Press.

Bulut, B., Cakmak, Z., \& Kara, C. (2013). Global Citizenship in Technology Age from the Perspective of Social Sciences. 13th International Educational Technology Conference (pp. 486-491). Kuala Lumpur: University of Malaya.

Chomsky, N. (2015, April 17). US is world's biggest terrorist. (Global-Conversation, Interviewer)

Cronin, C. (2009, April 18). The Dilemma of Cosmopolitanism and State Sovereignty. Retrieved Agustus 17, 2017, from E-International Relations Students: https://www.google.co.id/url?sa=t\&rct=j\&q=\&esrc=s\&source=web\&cd=1\&ved=0 ahUKEwjz__-

eoN7VAhXIrY8KHWTpBOgQFggrMAA\&url=http\%3A\%2F\%2Fwww.eir.info $\% 2 \mathrm{~F} 2009 \% 2 \mathrm{~F} 04 \% 2 \mathrm{~F} 18 \% 2 \mathrm{Fthe}$-dilemma-of-cosmopolitanism-and-statesovereignty\%2F\&usg=AFQjCNHIY0hg1UROZ6kzSET8sJA7zK0EKw

Donelly, J. (2007). The Relative Universality of Human Rights. Human Rights Quarterly Vol. 29 No. 2, 281-306.

Douthat, R. (2016, Juli 2). The Myth of Cosmopolitanism. Retrieved Agustus 17, 2017, from The New York Times: https://www.nytimes.com/2016/07/03/opinion/sunday/the-myth-ofcosmopolitanism.html?mcubz $=0$

Dudek, A. (2015, Agustus 27). All Americans Not Equal: Mistrust and Discrimination Against Naturalized Citizens in the U.S. Retrieved Agustus 17, 2017, from Huffington Post: http://www.huffingtonpost.com/alev-dudek/foreign-born-citizensin-america_b_8030968.htmll

Fine, R. (2003). Taking the "ism" out of cosmopolitanism; an essay in reconstruction. European Journal of Social Theory, VI(4), $451-470$.

Fukuyama, F. (1989). The End of History? The National Interest No. 16 , 3-18.

Haas, B. (2017, Juli 11). China moves to block internet VPNs from 2018. Retrieved Agustus 17, 2017, from The Guardian: 
https://www.theguardian.com/world/2017/jul/11/china-moves-to-block-internetvpns-from-2018

Hannerz, U. (2006). Two Faces of Cosmopolitanism: Culture and Politics. Barcelona: CIDOB.

Held, D. (2005). Principles of Cosmopolitan Order. In G. Brock, \& H. Brighouse (Eds.), The Political Philosophy of Cosmopolitanism (pp. 10-37). Cambridge: Cambridge University Press.

Hicks, S. (2009, Desember 12). Nationalism, not internationalism or cosmopolitanism. Retrieved Agustus 17, 2017, from Stephen Hicks, Ph.D.: http://www.stephenhicks.org/2009/12/12/nationalism-not-internationalism-orcosmopolitanism-section-9-of-nietzsche-and-the-nazis/

Johnson, R., \& Cureton, A. (2016, Juli 7). Kant's Moral Philosophy. Retrieved Agustus 17, 2017, from Stanford University: https://plato.stanford.edu/entries/kant-moral

Khazaal, C. (2016, Juli 10). Indigenous American Indians: Discrimination, A Pipeline and Columbus Day. Retrieved Agustus 17, 2017, from Huffington post: http://www.huffingtonpost.com/entry/indigenous-american-indians-discriminationa-pipeline_us_57f7b77ce4b0d786aa52afb8

Koga, K. (2013, Februari 22). ASEAN's Great Power Dilemma. Retrieved Agustus 17, 2017, from Harvard Kennedy School Belfer Center: http://www.belfercenter.org/publication/aseans-great-power-dilemma

Koser, K. (2013, October 30). Why Europe's immigration nightmare is only beginning. Retrieved May 14, 2017, from CNN: http://edition.cnn.com/2013/10/30/opinion/europe-immigration-debate-koser/

Koutonin, M. R. (2015, Maret 13). Why are white people expats when the rest of us are immigrants? Retrieved Agustus 17, 2017, from The Guardian: https://www.theguardian.com/global-development-professionalsnetwork/2015/mar/13/white-people-expats-immigrants-migration

Liu, E. (2012, Agustus 14). Why There's No Such Thing as Global Citizenship. Retrieved Agustus 17, 2017, from The Atlantic: https://www.theatlantic.com/national/archive/2012/08/why-theres-no-such-thingas-global-citizenship/261128/

Nussbaum, M. (1997). Kant and Cosmopolitanism. In J. Bohman, \& M. Lutz-Bachmann (Eds.), Perpetual Peace: Essays on Kant's Cosmopolitan Ideal (pp. 25-57). Cambridge: MIT Press.

O'Neill, O. (1990). Enlightenment as Autonomy: Kant's Vindication of Reason. In P. Hulme, \& L. Jordanova (Eds.), The Enlightenment and its Shadows. London: Rouledge.

Redfern, W. A. (2010). Sukarno's Guided Democracy and the Takeovers of Foreign Companies in Indonesia in the 1960s. Michigan: University of Michigan.

Rose, J. (2015, Januari 21). 10 Most Ridiculous Lies North Koreans Are Made to Believe. Retrieved Agustus 17, 2017, from The Richest: http://www.therichest.com/richlist/most-shocking/10-most-ridiculous-lies-north-koreans-are-made-to-believe/

Schmidt, J. (1998). Civility, Enlightenment, and Society: Conceptual Confusions and Kantian Remedies. American Political Science Review, XCII(2), 419-227.

Sobelman, B. (2015, September 8). Which countries are taking in Syrian refugees? Retrieved Agustus 17, 2017, from Los Angeles Times: http://www.latimes.com/world/europe/la-fg-migrants-scorecard-20150908story.html 
Spindler, M. (2002). New Regionalism and the Construction of Global Order. Coventry: CSGR.

Sugiono, M. (2012). Cosmopolitanism and World Politics Bringing the Global World to International Relations. Global \& Strategis, VI(2), 217-230.

Taraborrelli, A. (2015). Contemporary Cosmopolitanism (1st ed.). London: Bloomsbury.

Walt, S. M. (2016, Juni 26). The Collapse of the Liberal World Order. Retrieved Agustus 17, 2017, from Foreign Policy: http://foreignpolicy.com/2016/06/26/the-collapseof-the-liberal-world-order-european-union-brexit-donald-trump/ 